\title{
Ubiquitin carboxy-terminal hydrolase L1 (UCHL1) S18Y polymorphism in Alzheimer's disease
}

\author{
Madeleine Zetterberg ${ }^{1 *}$, Annica Sjölander ${ }^{2}$, Malin von Otter ${ }^{2}$, Mona Seibt Palmér $^{3}$, Sara Landgren ${ }^{4}$, \\ Lennart Minthon ${ }^{5,6}$, Anders Wallin², Niels Andreasen ${ }^{7}$, Kaj Blennow ${ }^{2}$, Henrik Zetterberg ${ }^{2}$
}

\begin{abstract}
Alzheimer's disease (AD) is characterized by protein aggregates, i.e. senile plaques and neurofibrillary tangles. The ubiquitin-proteasome system has been proposed a role in proteolytic removal of these protein aggregates. Ubiquitin carboxy-terminal hydrolase L1 (UCHL1) is a de-ubiquitinating enzyme with important functions in recycling of ubiquitin. The S18Y polymorphism of the UCHL1 gene confers protection against Parkinson's disease. In this study, the genotype and allele frequencies of the UCHL1 S18Y polymorphism were investigated in 452 AD patients and 234 control subjects, recruited from four memory clinics in Sweden. Using a binary logistic regression model including UCHL1 allele A and APOE $\varepsilon 4$ allele positivity, age and sex as covariates with AD diagnosis as dependent variable, an adjusted OR of 0.82 ([95\% Cl 0.55-1.24], $P=0.35$ ) was obtained for a positive UCHL1 allele A carrier status. The present study thus do not support a protective effect of the UCHL1 S18Y polymorphism against AD.
\end{abstract}

\section{Findings}

Aggregation of aberrant proteins is a hallmark of several neurodegenerative diseases, including Alzheimer's (AD), Huntington's (HD) and Parkinson's (PD) diseases. In this context, the ubiquitin-proteasome system (UPS) has been ascribed a central role in preventing the formation of pathological protein aggregates by proteolytic removal of defect proteins [1]. Proteins destined for degradation by the UPS are labelled with a 76-amino acid peptide, ubiquitin, through a series of conjugation steps by the E1, E2 and E3 enzymes respectively. There are also two classes of de-ubiquitinating enzymes; the ubiquitin-specific processing proteases (UBPC) and the ubiquitin carboxy-terminal hydrolase family (UHC). For recent reviews on the UPS, see [2,3]. Ubiquitin carboxy-terminal hydrolase L1 (UCHL1) is an isoform of the UHC group, expressed mainly in neurons and testis/ovary. However, UCHL1 has also been found in cells of the human diffuse neuroendocrine system and is expressed is several forms of cancer [4-6]. UCHL1 has an important role in recycling of ubiquitin through hydrolysis of peptide-ubiquitin bonds and processing of ubiquitin precursors, but it also possesses ubiquitin ligase activity [7].

\footnotetext{
* Correspondence: madeleine.zetterberg@gu.se ${ }^{1}$ Institute of Neuroscience and Physiology, Department of Clinical Neuroscience and Rehabilitation, Section of Ophthalmology, The Sahlgrenska Academy at the University of Gothenburg, Mölndal, Sweden
}

Moreover, it has been shown that UCHL1 associates with monoubiquitin and elongates its half-life, thus ensuring stability of ubiquitin within neurons [8].

Several genetic variants of the $U C H L 1$ gene have been described; both those leading to gain-of-function and those resulting in loss-of-function. The I93 M mutant results in $50 \%$ reduced activity [9], whereas the S18Y variant exhibits increased hydrolytic activity [10]. Other studies showed comparable hydrolase activity of the UCHL1 S18Y variant when compared to the wild type enzyme, but a reduction in ligase activity [11]. It has also been demonstrated that the UCHL1 S18Y polymorphism has a specific ability to act as a potent antioxidant in neuronal cell culture systems [12].

A number of reports have demonstrated a protective effect of the S18Y polymorphism against sporadic PD in different populations [13-16], although conflicting data exist [17]. As for $\mathrm{AD}$, data on $U C H L 1$ genotype frequencies and its effect on risk of AD is scarce and conflicting $[18,19]$. The purpose of this study was to investigate the UCHL1 S18Y polymorphism in AD patients and controls in the Swedish population. Given that we, for subsets of the participants, have previously collected data on levels of CSF biochemical markers and neuropathological scores for $\mathrm{AD}$, associations between the UCHL1 S18Y polymorphism and these variables could be investigated in addition to the genetic risk analysis. 
The study population consisted of 452 patients with AD and 234 subjects without dementia, all of Swedish nationality. The AD patients and control subjects were recruited and diagnosed from four memory clinics in Sweden; Malmö (371 patients, 48 controls), Huddinge (52 patients, 70 controls), Göteborg/Mölndal (29 patients, 95 controls) and Linköping (21 controls). The patients were invited to participate at their first visit to the respective clinic, where they also gave their informed consent. The control subjects were recruited by advertisement in the local newspapers or at senior citizen organization meetings. A few of these controls were spouses or unrelated friends of the patients. The study was approved by the local Ethical Commissions at the respective academic center and the tenets of the Declaration of Helsinki were followed. Parts of the AD and the control groups in this work have also been included in previous studies on other polymorphisms [20,21].

All AD patients underwent clinical examination, neuropsychological evaluations including Mini-Mental State Examinaton (MMSE), computed tomography (CT) or magnetic resonance imaging (MRI) of the brain and routine blood analyses. The healthy elderly controls were classified as non-demented on the basis of a structured interview performed by a research nurse that included information on health history, lifestyle-related variables and psychosocial situation. Only controls with an MMSE score of at least 26 were included in the study. In addition, 65 years was set as the youngest age of controls for participation in the study.

Patients were clinically diagnosed with probable lateonset AD according to the NINCDS-ADRDA criteria [22] by a dementia investigation team that included specialists in geriatric medicine and psychiatry. To avoid inclusion of cases with familial Alzheimer's disease (FAD) only patients 60 years of age or older were included in the study. In addition, all patients were questioned about their family history regarding AD and those with suspect heredity were excluded. Individuals with significant psychiatric or somatic diseases other than AD were excluded. Data on CSF biomarkers, including the concentrations of total-tau (T-tau), phospho-tau ${ }_{181}\left(\mathrm{P}-\mathrm{tau}_{181}\right)$ and $\mathrm{A} \beta_{1-42}$ was available for 260 of the AD patients and 117 of the controls. Neuropathological diagnosis and scores based on senile plaques and neurofibrillary tangles were available for 65 of the AD patients and 80 of the controls. Genomic DNA was extracted from whole blood samples and brain tissue using standard methods. APOE (gene map locus 19q13.2) genotyping had previously been performed by minisequencing, as described in detail [23].

The UCHL1 (gene map locus 4p14; [Entrez gene ID: 7345]) S18Y, 54C>A polymorphism (rs5030732) was analyzed using the Dynamic Allele Specific Amplification (DASH) tehnology as described earlier [24]. The PCR were carried out with HotStarTaq DNA Polymerase $^{\ominus}$ (QIAGEN, Hilden, Germany) in a final volume of $25 \mu \mathrm{l}$, containing 5-20 ng of template DNA. Optimal conditions were: $1 \mathrm{mM} \mathrm{MgCl} 2,0.2 \mathrm{mM}$ dNTPs, $0.02 \mathrm{U}$ Taq polymerase, $0.16 \mathrm{pmol} / \mu \mathrm{l}$ of the forward biotinylated primer (5'Biotin-GCCGCCTTGTCTCCTCTCAGCAG3') and $0.78 \mathrm{pmol} / \mu \mathrm{l}$ of the reverse primer (5'GTCACTGGCCTGCGACCCC3'), (Invitrogen, Paisley, UK) in $1 \times$ PCR buffer (Roche, Mannheim, Germany). The cycling profile was: $15 \mathrm{~min}$ at $95^{\circ} \mathrm{C}$, then 39 cycles: $30 \mathrm{sec}$ at $95^{\circ} \mathrm{C}, 45 \mathrm{sec}$ at $60^{\circ} \mathrm{C}, 45 \mathrm{sec}$ at $72^{\circ} \mathrm{C}$ and finally $10 \mathrm{~min}$ at $72^{\circ} \mathrm{C}$. To identify $U C H L 1$ alleles the probe 5'GACAGAAACGCACTTGT-Rox3' (MWG Biotech, London, United Kingdom) was used. The accuracy of the DASH method was verified by DNA sequencing of 15 individuals representing the different $U C H L 1$ genotypes (five of each genotype).

Primary analyses compared differences between the AD patients and control subjects regarding age, sex, MMSE score, biochemical markers, neuropathological scores, genotype and allele frequencies using Fisher's exact $\chi^{2}$ test, $t$-test and Mann-Whitney U test. Secondary analysis of $U C H L 1$ allele A-carrier status was performed with a binary logistic regression model with diagnosis (AD versus control) as dependent variable and allele positivity, age, sex and $A P O E \& 4$ allele status as independent variables. Significance was set at $P<0.05$. SPSS 16.0 (SPSS Inc, Chicago, Il) was used as statistic software.

In the $\mathrm{AD}$ group the mean age was 76.2 (SD 6.4) years (range 60-102 years) and 299 (66.2\%) were women. In the control group the mean age was 75.9 (SD 7.1) years (range 65-94 years) and 127 (58.8\%) were women. A summary of demographic and clinical characteristics is presented in table 1, including MMSE score, CSF biomarkers, neuropathological score and APOE \&4 allelecarrier status.

Genotype and allele frequencies for the UCHL1 S18Y polymorphism are shown in table 2 . There was a significant overrepresentation of the heterozygous genotype $(\mathrm{AC})$ in the control group $(\mathrm{p}=0.03)$. There were no significant differences between the controls and the cases with regard to the homozygous genotypes however, even if the $\mathrm{CC}$ genotype was overrepresented among the $\mathrm{AD}$ patients with a border-line p-value (0.054). In addition, when analyzing $U C H L 1$ allele A-carrier status (dominant approach) a positive allele A-carrier status was slightly overrepresented in the control group $(\mathrm{p}=0.054)$. The distributions of the $U C H L 1$ genotypes were in HardyWeinberg equilibrium for the control group $(P=0.602$ for AA, $P=0.692$ for AC and $P=0.846$ for $C C$ ) as well as for the $\mathrm{AD}$ group $(P=0.436$ for $\mathrm{AA}, P=0.647$ for $\mathrm{AC}$ and $P=0.825$ for $\mathrm{CC}$ ). 
Table 1 Demographic, clinical and genetic characteristics of patients with AD and controls

\begin{tabular}{|c|c|c|c|}
\hline Characteristic & AD patients $(n=452)$ & Controls $(n=234)$ & $P$-value \\
\hline \multirow[t]{2}{*}{ Sex, f/m (\%) } & 299/153 (66.2/33.8) & $127 / 89(58.8 / 41.2)$ & $0.071^{*}$ \\
\hline & $n=452$ & $n=216$ & \\
\hline Age, years, & $76.2 \pm 6.4(60-102)$ & $75.9 \pm 7.1(65-94)$ & $0.215^{\dagger}$ \\
\hline Mean \pm SD (range) & $\mathrm{n}=341$ & $n=216$ & \\
\hline MMSE score, Median ( $25^{\text {th }}-75^{\text {th }}$ percentiles) & $22(19-25) n=367$ & $29(29-30) n=113$ & $<0.001^{\ddagger}$ \\
\hline T-tau $(p g / m l)$, Mean \pm SD & $621 \pm 319 n=260$ & $376 \pm 162 n=117$ & $<0.001^{\dagger}$ \\
\hline P-tau $181(p g / m l)$, Mean \pm SD & $76.9 \pm 31.2 n=260$ & $63.3 \pm 19.9 n=91$ & $<0.001^{\dagger}$ \\
\hline$A \beta_{1-42}(p g / m l)$, Mean $\pm S D$ & $409 \pm 100 n=260$ & $720 \pm 200 n=117$ & $<0.001^{\dagger}$ \\
\hline SPs and NFTs score, Median ( $25^{\text {th }}-75^{\text {th }}$ percentiles) & $7(6-8.5) n=65$ & $1(0-3) n=80$ & $<0.001^{\dagger}$ \\
\hline \multicolumn{4}{|l|}{$\begin{array}{l}\text { APOE } \varepsilon 4 \text { allele-carriers n (\%) } \\
\text { number of } \varepsilon 4 \text { alleles: }\end{array}$} \\
\hline 0 & $128(28.3)$ & $156(72.2)$ & $<0.001^{*}$ \\
\hline 1 & $238(52.7)$ & $55(25.5)$ & $<0.001^{*}$ \\
\hline \multirow[t]{2}{*}{2} & $86(19.0)$ & $5(2.3)$ & $<0.001^{*}$ \\
\hline & $n=452$ & $n=216$ & \\
\hline
\end{tabular}

*Fisher's Exact Test, ${ }^{\dagger}$ Mann-Whitney U-test. AD = Alzheimer's disease, SD = Standard Deviation, MMSE = Mini Mental State Examination, A $\beta=\beta$-amyloid, SPs = senile plaques, NFTs = neurofibrillary tangles

Table 2 UCHL1 genotype and allele frequencies in patients with AD and controls

\begin{tabular}{|c|c|c|c|}
\hline $\begin{array}{l}\text { UCHL1 genotype } \\
\text { frequencies, } \mathrm{n}(\%)\end{array}$ & AD patients $(n=452)$ & Controls $(n=234)$ & $P$-value* \\
\hline$\overline{\mathrm{AA}}$ & $15(3.3)$ & $6(2.6)$ & 0.649 \\
\hline$A C$ & $112(24.8)$ & 77 (32.9) & 0.030 \\
\hline CC & $325(71.9)$ & $151(64.5)$ & 0.054 \\
\hline \multicolumn{4}{|c|}{$U C H L 1$ allele frequencies, $\mathrm{n}(\%)^{\dagger}$} \\
\hline allele A & $142(15.7)$ & $89(19.0)$ & 0.128 \\
\hline allele C & $762(84.3)$ & $379(81.0)$ & \\
\hline UCHL1 allele A-carrier n (\%) & $127(28.1)$ & $83(35.5)$ & 0.054 \\
\hline UCHL1 allele C-carrier n (\%) & $437(96.7)$ & $228(97.4)$ & 0.649 \\
\hline
\end{tabular}

*Fisher's Exact Test, ${ }^{\dagger}$ There are two alleles per subject, yielding $n=904$ for $A D$ patients and $n=468$ for controls. AD = Alzheimer's disease.

Using a binary logistic regression model including $U C H L 1$ allele $\mathrm{A}$ and $A P O E \& 4$ allele positivity, age and sex as covariates with $\mathrm{AD}$ diagnosis as dependent variable, an adjusted OR of 0.82 ([95\% CI 0.55-1.24], $P=$ 0.35 ) was obtained for a positive $U C H L 1$ allele A carrier status (table 3). On the basis of previously reported $U C H L 1$ allele frequencies, a standardized difference of 0.29 was calculated [15]. This yielded a power of the study of $96 \%$, indicating that the lack of association was not spurious. CSF T-tau, P-tau 181 or $\mathrm{A} \beta_{1-42}$ levels were not affected by the UCHL1 S18Y polymorphism (Table 4). Neither did neuropathological scores of senile plaques and neurofibrillary tangles exhibit any associations with the $U C H L 1$ polymorphism (Table 4). Further, we compared the UCHL1 allele A-positivity for AD patients and control subjects respectively between the different centers and found no differences (not shown).
Aggregation of proteins is a major feature of several neurodegenerative disorders, including Alzheimer's disease (AD). Several lines of evidence suggest that the ubiquitin-proteasome system (UPS) is involved in the pathogenesis of $\mathrm{AD}$ [1]. Accumulation of ubiquitin in senile plaques and neurofibrillary tangles [25-28], changes in proteasome subunit composition in $\mathrm{AD}$ [29] and an association of AD with polymorphic variants of UBQLN1, encoding for ubiquilin which is a ubiquitin-like protein [30], are some of the signs pointing towards a role of the UPS in AD. Of special interest is the finding that UCHL1 is oxidized in AD and that it is down-regulated in affected brain areas of $\mathrm{AD}$ patients [31,32]. Also interesting is the finding that exogenous UCHL1 ameliorated $\beta$-amyloid-induced synaptic and memory dysfunction in an AD mouse model [33]. 
Table 3 Binary logistic regression of AD diagnosis versus $U C H L 1$ allele A- and APOE allele $\varepsilon 4$-carrier status, age and gender.

\begin{tabular}{lccccc}
\hline Variable, $\mathbf{n}=\mathbf{5 5 7}$ & $\mathbf{B}$ & $\mathbf{S . E .}$ & $\mathbf{O R}$ & $\mathbf{9 5 \% C l}$ & $\boldsymbol{P}$-value \\
\hline Female gender & 0.29 & 0.20 & 1.34 & $0.90-2.00$ & 0.147 \\
Age, years & 0.01 & 0.02 & 1.01 & $0.98-1.04$ & 0.456 \\
UCHL1, allele A positivity & -0.20 & 0.21 & 0.82 & $0.55-1.24$ & 0.348 \\
APOE, allele $\varepsilon 4$ positivity & 1.96 & 0.20 & 7.09 & $4.83-10.4$ & $<0.000$
\end{tabular}

$\mathrm{AD}=$ Alzheimer's disease, $\mathrm{B}=$ Regression coefficient, S.E. = Standard error, $\mathrm{OR}$ = Adjusted odds ratio, $\mathrm{Cl}=$ Confidence interval

Table 4 CSF biomarkers and neuropathological score in relation to UCHL1 allele A-carrier status in AD patients and control subjects

\begin{tabular}{llll}
\hline & \multicolumn{2}{l}{$\begin{array}{l}\text { UCHL1 allele A-carrier } \\
\text { status }\end{array}$} & \\
positive & negative & P-value* $^{*}$ \\
\hline T-tau $(\mathrm{pg} / \mathrm{ml})$, Mean $\pm \mathrm{SD}$ & & & \\
AD patients & $640 \pm 368$ & $613 \pm 297$ & 0.790 \\
Controls & $367 \pm 175$ & $381 \pm 156$ & 0.528 \\
& & & \\
P-tau & & & \\
AD patients & & & 0.434 \\
Controls & $80.6 \pm 35.1$ & $75.3 \pm 29.4$ & 0.159
\end{tabular}

$A \beta_{1-42}(p g / m l)$, Mean $\pm S D$

$\begin{array}{llll}\text { AD patients } & 406 \pm 91.5 & 410 \pm 104 & 0.996 \\ \text { Controls } & 749 \pm 195 & 703 \pm 202 & 0.246\end{array}$

SPs and NFTs score

Median $\left(25^{\text {th }}-75^{\text {th }}\right.$ percentiles $)$

$\begin{array}{llll}\text { AD patients } & 7(5-8) & 7(6-9) & 0.495 \\ \text { Controls } & 2(0-3.5) & 0(0-2) & 0.122\end{array}$

$\mathrm{CSF}=$ cerebrospinal fluid, $\mathrm{AD}=$ Alzheimer's disease, $\mathrm{SPs}=$ senile plaques, NFTs = neurofibrillary tangles, $A \beta=\beta$-amyloid, *Mann-Whitney U-test

The S18Y polymorphism of the UCHL1 gene is associated with lower incidence of Parkinson's disease [13-16]. The mechanism for this protective effect is not known, but it may be at least partially explained by the increased antioxidative capacity demonstrated in neuronal cells expressing the UCHL1 S18Y variant [12]. Little is known about its effect on $\mathrm{AD}$ prevalence. A Chinese study has demonstrated lower frequencies of the A allele and the AA genotype in female AD patients as compared to female controls [19]. However, a genetic study in a Colombian population could not find an association between UCHL1 genotypes and AD [18]. The number of genome-wide association studies in the AD field has increased rapidly; none of these has reported the UCHL1 S18Y polymorphism among the significant SNPs found however [34,35].

The allele and genotype frequencies of the UCHL1 S18Y polymorphism seen in this study are in accordance with previous results in Swedish populations [13]. The present study do not support a role of the UCHL1 S18Y polymorphism AD however.

\section{Acknowledgements}

This work was supported by grants from the Swedish Research Council, the Royal Swedish Academy of Sciences, the Sahlgrenska University Hospital, the Göteborg Medical Society, Swedish Brain Power, Hjalmar Svenssons forskningsfond, Stiftelsen för Gamla Tjänarinnor and Alzheimerfonden.

\section{Author details}

${ }^{1}$ Institute of Neuroscience and Physiology, Department of Clinical Neuroscience and Rehabilitation, Section of Ophthalmology, The Sahlgrenska Academy at the University of Gothenburg, Mölndal, Sweden. ${ }^{2}$ Institute of Neuroscience and Physiology, Department of Psychiatry and Neurochemistry, The Sahlgrenska Academy at the University of Gothenburg, Mölndal, Sweden. ${ }^{3}$ Institute of Biomedicine, Department of Clinical Chemistry and Transfusion Medicine, The Sahlgrenska Academy at the University of Gothenburg, Göteborg, Sweden. ${ }^{4}$ Institute of Neuroscience and Physiology, Department of Pharmacology, The Sahlgrenska Academy at the University of Gothenburg, Göteborg, Sweden. ${ }^{5}$ Clinical Memory Research Unit, Department of Clinical Sciences, Lund University, Lund, Sweden.

${ }^{6}$ Neuropsychiatric Clinic, Malmö University Hospital, Malmö, Sweden.

${ }^{7}$ Memory clinic, M51, Department of Geriatric Medicine, Karolinska University Hospital, Huddinge, Stockholm, Sweden.

\section{Authors' contributions}

$\mathrm{MZ}$ participated in the design of the study, analyzed the data statistically and drafted the manuscript. AS performed genetic analyses and helped to draft the manuscript. MvO, MSP and SL performed genetic analyses and revised the manuscript critically. LM, AW and NA collected clinical material and revised the manuscript critically. $K B$ participated in the design of the study and revised the manuscript critically. $\mathrm{HZ}$ conceived of the study, helped in analyzing the data and helped in drafting the manuscript. All authors have read and approved the final manuscript.

\section{Competing interests}

The authors declare that they have no competing interests.

Received: 23 November 2009 Accepted: 19 March 2010 Published: 19 March 2010

\section{References}

1. Oddo S: The ubiquitin-proteasome system in Alzheimer's disease. J Cell Mol Med 2008, 12:363-373.

2. Petroski MD: The ubiquitin system, disease, and drug discovery. BMC Biochem 2008, 9(Suppl 1):S7.

3. Tai HC, Schuman EM: Ubiquitin, the proteasome and protein degradation in neuronal function and dysfunction. Nat Rev Neurosci 2008, 9:826-838.

4. Dhillon AP, Rode J, Dhillon DP, Moss E, Thompson RJ, Spiro SG, Corrin B: Neural markers in carcinoma of the lung. Br J Cancer 1985, 51:645-652.

5. Otsuki T, Yata K, Takata-Tomokuni A, Hyodoh F, Miura Y, Sakaguchi H, Hatayama T, Hatada S, Tsujioka T, Sato Y, Murakami H, Sadahira Y, Sugihara T: Expression of protein gene product 9.5 (PGP9.5)/ubiquitin-Cterminal hydrolase 1 (UCHL-1) in human myeloma cells. Br J Haematol 2004, 127:292-298.

6. Thompson RJ, Doran JF, Jackson P, Dhillon AP, Rode J: PGP 9.5-a new marker for vertebrate neurons and neuroendocrine cells. Brain Res 1983, 278:224-228

7. Healy DG, Abou-Sleiman PM, Wood NW: Genetic causes of Parkinson's disease: UCHL-1. Cell Tissue Res 2004, 318:189-194.

8. Osaka H, Wang YL, Takada K, Takizawa S, Setsuie R, Li H, Sato Y, Nishikawa K, Sun YJ, Sakurai M, Harada T, Hara Y, Kimura I, Chiba S, Namikawa K, Kiyama H, Noda M, Aoki S, Wada K: Ubiquitin carboxyterminal hydrolase L1 binds to and stabilizes monoubiquitin in neuron. Hum Mol Genet 2003, 12:1945-1958.

9. Leroy E, Boyer R, Auburger G, Leube B, Ulm G, Mezey E, Harta G, Brownstein MJ, Jonnalagada S, Chernova T, Dehejia A, Lavedan C, Gasser T, 
Steinbach PJ, Wilkinson KD, Polymeropoulos MH: The ubiquitin pathway in Parkinson's disease. Nature 1998, 395:451-452.

10. Setsuie R, Wada K: The functions of UCH-L1 and its relation to neurodegenerative diseases. Neurochem Int 2007, 51:105-111.

11. Liu Y, Fallon L, Lashuel HA, Liu Z, Lansbury PT Jr: The UCH-L1 gene encodes two opposing enzymatic activities that affect alpha-synuclein degradation and Parkinson's disease susceptibility. Cell 2002, 111:209-218

12. Kyratzi E, Pavlaki M, Stefanis L: The S18Y polymorphic variant of UCH-L1 confers an antioxidant function to neuronal cells. Hum Mol Genet 2008, 17:2160-2171

13. Carmine Belin A, Westerlund M, Bergman O, Nissbrandt $H$, Lind $C$, Sydow $O$, Galter D: S18Y in ubiquitin carboxy-terminal hydrolase L1 (UCH-L1) associated with decreased risk of Parkinson's disease in Sweden. Parkinsonism Relat Disord 2007, 13:295-298.

14. Elbaz A, Levecque C, Clavel J, Vidal JS, Richard F, Correze JR, Delemotte B, Amouyel P, Alperovitch A, Chartier-Harlin MC, Tzourio C: S18Y polymorphism in the UCH-L1 gene and Parkinson's disease: evidence for an age-dependent relationship. Mov Disord 2003, 18:130-137.

15. Maraganore DM, Farrer MJ, Hardy JA, Lincoln SJ, McDonnell SK, Rocca WA: Case-control study of the ubiquitin carboxy-terminal hydrolase L1 gene in Parkinson's disease. Neurology 1999, 53:1858-1860.

16. Maraganore DM, Lesnick TG, Elbaz A, Chartier-Harlin MC, Gasser T, Kruger R, Hattori N, Mellick GD, Quattrone A, Satoh J, Toda T, Wang J, loannidis JP, de Andrade M, Rocca WA: UCHL1 is a Parkinson's disease susceptibility gene. Ann Neurol 2004, 55:512-521.

17. Hutter CM, Samii A, Factor SA, Nutt JG, Higgins DS, Bird TD, Griffith A, Roberts JW, Leis BC, Montimurro JS, Kay DM, Edwards KL, Payami H, Zabetian CP: Lack of evidence for an association between UCHL1 S18Y and Parkinson's disease. Eur J Neurol 2008, 15:134-139.

18. Forero DA, Benitez B, Arboleda G, Yunis JJ, Pardo R, Arboleda H: Analysis of functional polymorphisms in three synaptic plasticity-related genes (BDNF, COMT AND UCHL1) in Alzheimer's disease in Colombia. Neurosci Res 2006, 55:334-341.

19. Xue S, Jia J: Genetic association between Ubiquitin Carboxy-terminal Hydrolase-L1 gene S18Y polymorphism and sporadic Alzheimer's disease in a Chinese Han population. Brain Res 2006, 1087:28-32.

20. Andersson ME, Sjolander A, Andreasen N, Minthon L, Hansson O, Bogdanovic N, Jern C, Jood K, Wallin A, Blennow K, Zetterberg H: Kinesin gene variability may affect tau phosphorylation in early Alzheimer's disease. Int J Mol Med 2007, 20:233-239.

21. Zetterberg M, Landgren $S$, Andersson ME, Palmer MS, Gustafson DR, Skoog I, Minthon L, Thelle DS, Wallin A, Bogdanovic N, Andreasen N, Blennow K, Zetterberg $\mathrm{H}$ : Association of complement factor $\mathrm{H} Y 402 \mathrm{H}$ gene polymorphism with Alzheimer's disease. Am J Med Genet B Neuropsychiatr Genet 2007, 147B(6):720-6.

22. McKhann G, Drachman D, Folstein M, Katzman R, Price D, Stadlan EM: Clinical diagnosis of Alzheimer's disease: report of the NINCDS-ADRDA Work Group under the auspices of Department of Health and Human Services Task Force on Alzheimer's Disease. Neurology 1984, 34:939-944.

23. Blennow K, Ricksten A, Prince JA, Brookes AJ, Emahazion T, Wasslavik C, Bogdanovic N, Andreasen N, Batsman S, Marcusson J, Nagga K, Wallin A, Regland B, Olofsson H, Hesse C, Davidsson P, Minthon L, Jansson A, Palmqvist $L$, Rymo $L$ : No association between the alpha2-macroglobulin (A2 M) deletion and Alzheimer's disease, and no change in A2 M mRNA, protein, or protein expression. J Neural Transm 2000, 107:1065-1079.

24. Prince JA, Feuk L, Howell WM, Jobs M, Emahazion T, Blennow K, Brookes AJ: Robust and accurate single nucleotide polymorphism genotyping by dynamic allele-specific hybridization (DASH): design criteria and assay validation. Genome Res 2001, 11:152-162.

25. Ii $\mathrm{K}$, Ito H, Tanaka K, Hirano A: Immunocytochemical co-localization of the proteasome in ubiquitinated structures in neurodegenerative diseases and the elderly. J Neuropathol Exp Neurol 1997, 56:125-131.

26. Mori $\mathrm{H}$, Kondo J, Ihara $\mathrm{Y}$ : Ubiquitin is a component of paired helical filaments in Alzheimer's disease. Science 1987, 235:1641-1644.

27. Perry G, Friedman R, Shaw G, Chau V: Ubiquitin is detected in neurofibrillary tangles and senile plaque neurites of Alzheimer disease brains. Proc Natl Acad Sci USA 1987, 84:3033-3036.

28. Tabaton M, Cammarata S, Mancardi G, Manetto V, Autilio-Gambetti L, Perry G, Gambetti P: Ultrastructural localization of beta-amyloid, tau, and ubiquitin epitopes in extracellular neurofibrillary tangles. Proc Natl Acad Sci USA 1991, 88:2098-2102
29. Mishto M, Bellavista E, Santoro A, Stolzing A, Ligorio C, Nacmias B, Spazzafumo L, Chiappelli M, Licastro F, Sorbi S, Pession A, Ohm T, Grune T, Franceschi C: Immunoproteasome and LMP2 polymorphism in aged and Alzheimer's disease brains. Neurobiol Aging 2006, 27:54-66.

30. Bertram L, Hiltunen M, Parkinson M, Ingelsson M, Lange C, Ramasamy K, Mullin K, Menon R, Sampson AJ, Hsiao MY, Elliott K, Velicelebi G, Moscarillo T, Hyman BT, Wagner SL, Becker KD, Blacker D, Tanzi RE: Familybased association between Alzheimer's disease and variants in UBQLN1. N Engl J Med 2005, 352:884-894

31. Castegna A, Aksenov M, Aksenova M, Thongboonkerd V, Klein JB, Pierce WM, Booze R, Markesbery WR, Butterfield DA: Proteomic identification of oxidatively modified proteins in Alzheimer's disease brain. Part I: creatine kinase BB, glutamine synthase, and ubiquitin carboxy-terminal hydrolase L-1. Free Radic Biol Med 2002, 33:562-571.

32. Pasinetti GM: Use of cDNA microarray in the search for molecular markers involved in the onset of Alzheimer's disease dementia. Neurosci Res 2001, 65:471-476.

33. Gong B, Cao Z, Zheng P, Vitolo OV, Liu S, Staniszewski A, Moolman D, Zhang $\mathrm{H}$, Shelanski M, Arancio O: Ubiquitin hydrolase Uch-L1 rescues beta-amyloid-induced decreases in synaptic function and contextual memory. Cell 2006, 126:775-788.

34. Beecham GW, Martin ER, Li YJ, Slifer MA, Gilbert JR, Haines JL, PericakVance MA: Genome-wide association study implicates a chromosome 12 risk locus for late-onset Alzheimer disease. Am J Hum Genet 2009, 84:35-43.

35. Harold D, Abraham R, Hollingworth P, Sims R, Gerrish A, Hamshere ML, Pahwa JS, Moskvina V, Dowzell K, Williams A, Jones N, Thomas C, Stretton A, Morgan AR, Lovestone S, Powell J, Proitsi P, Lupton MK, Brayne C, Rubinsztein DC, Gill M, Lawlor B, Lynch A, Morgan K, Brown KS, Passmore PA, Craig D, McGuinness B, Todd S, Holmes C, et al: Genomewide association study identifies variants at CLU and PICALM associated with Alzheimer's disease. Nat Genet 2009, 41:1088-1093.

\section{doi:10.1186/1750-1326-5-11}

Cite this article as: Zetterberg et al:: Ubiquitin carboxy-terminal hydrolase L1 (UCHL1) S18Y polymorphism in Alzheimer's disease. Molecular Neurodegeneration 2010 5:11.

\section{Submit your next manuscript to BioMed Central and take full advantage of:}

- Convenient online submission

- Thorough peer review

- No space constraints or color figure charges

- Immediate publication on acceptance

- Inclusion in PubMed, CAS, Scopus and Google Scholar

- Research which is freely available for redistribution 